\title{
Betydningen av sosiale forhold for mental helse og selvmordsatferd
}

\author{
Av Lisa Victoria Burrell, Quirino Puzo, Lars Mehlum og Ping Qin
}

\section{SAMMENDRAG}

Lav sosioøkonomisk status og lite sosial støtte er risikofaktorer for dårlig fysisk og mental helse, selvmord og selvskading. Denne robuste sammenhengen kan enten skyldes at dårlige sosiale forhold forårsaker dårlig helse, eller at psykiske lidelser forringer individers sosiale forhold. Negative eller manglende sosiale forhold kan på sin side forårsake psykisk uhelse gjennom konstante og direkte effekter eller gjennom indirekte buffereffekter der gunstige sosiale forhold reduserer påvirkningen av negative livshendelser. Inngående kunnskap om sosiale forhold er uansett viktig for effektiv forebygging av psykiske lidelser og selvmordsatferd, og denne artikkelen vil derfor belyse betydningen av sosiale forhold for mental helse og selvmordsatferd gjennom å rette søkelyset mot noen overordnede teorier. Vi vil også benytte eksempler fra egne empiriske studier for å illustrere hvordan sosiale forhold kan ha betydning for forekomsten av selvmord i nordiske befolkningsutvalg.

Low socioeconomic status and social support are risk factors for poor physical and mental health, suicide and self-harm. This robust association can either be because poor social conditions cause a decline in health or because psychiatric disorders deteriorate individuals' social conditions. Negative or lacking social conditions can furthermore cause mental ill-health through constant direct effects or through indirect buffer effects where favorable social conditions reduce the influence of negative life events. Thorough knowledge about social conditions is irrespectively important for effective prevention of psychiatric disorders and suicidal behavior, and the present article will hence elucidate the importance of social conditions for mental health and suicidal behavior by focusing on some major theoretical approaches. We will also use examples from our own empirical studies in order to illustrate how social conditions can influence the occurrence of suicide in Nordic populations.

ENSOMHET HAR BLITT KALT vår tids folkesykdom. Data fra Statistisk sentralbyrå viser at $15 \%$ av voksne ikke har noen å spørre om råd eller hielp, og nesten 1 av 4 unge under 30 år oppgir at de opplever ensomhet (Thorsen og Clausen 2009, Vrålstad 2017). Ensomhet og lav sosial støtte har vist seg å være risikofaktorer for dårlig fysisk og mental helse, samt selvmord og selvskading. Eksempelvis fant en norsk studie at elever på videregående skole som rapporterte mindre sosial støtte fra familie, venner og klassekamerater opplevde mer psykisk stress enn de som opplevde god sosial støtte (Ystgaard 1997). I denne studien ble sosial støtte påvist som en viktig faktor som medierte en stor del av assosiasjonen mellom psykisk stress og utvikling av depresjonssymptomer og selvmordstanker. Likeledes har omfattende nasjonale studier rapportert at risikoen for selvmord og selvmordsforsøk er større blant enslige og de med lav støtte fra venner og familie (Qin, Agerbo et al. 2003, Kleiman og Liu 2013). Émile Durkheim påpekte denne sammenhengen mellom det han kalte sosial integrasion og selvmord allerede i sin velkjente monografi «Selvmordet» i 1897, og mente at et dysfunksjonelt forhold til familie, venner eller samfunnet i sin helhet kunne lede til selvmord (Durkheim 1897/1966). Inngående kunnskap om sosiale forhold er med andre ord viktig for effektiv forebygging av selvmordsatferd. 


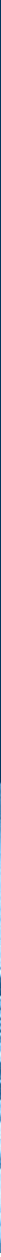

Sosiale forhold er faktorer som involverer en persons forhold og relasioner til andre mennesker (Link og Phelan 1995). Dette inkluderer alt fra nære relasjoner mellom enkeltmennesker, til den sosiale statusen et menneske har i samfunnet basert på blant annet inntekt, utdanning og etnisitet. Sosiale forhold omhandler dermed relasioner på flere nivåer, fra et mellommenneskelig nivå til et samfunnsnivå, og innbefatter begreper som sosial støtte, sosiale nettverk, sosial isolasion og sosioøkonomisk status. Disse begrepene er altså relaterte, noe som også støttes av nyere norske undersøkelser som viser at voksne som er arbeidsledige, har lav utdanning eller lav inntekt også har lavest sosial støtte og opplever mest ensomhet (Vrålstad 2017). Sosial støtte og sosial tilhørighet kan komme fra flere kilder, slik som foreldre eller søsken, ektefelle eller partner, besteforeldre, annen slekt, venner, naboer, kollegaer eller lærere, idrettslag, foreninger eller støttegrupper. Denne artikkelen vil belyse betydningen av sosiale forhold for mental helse og selvmordsatferd giennom å rette søkelyset mot noen overordnede prinsipper og teorier om sosiale forhold og mestring. Vi vil dessuten benytte eksempler fra egne empiriske studier for å illustrere hvordan sosiale forhold kan ha betydning for forekomsten av selvmord i nordiske befolkningsutvalg.

\section{Sosial kausalitet og sosial seleksjon}

Den rapporterte assosiasionen mellom sosiale forhold og mental helse kan være forårsaket av to ulike årsakssammenhenger: Dårlige sosiale forhold kan lede til nedsatt mental helse, eller dårlig mental helse kan lede til forverring i sosiale forhold. Dette er henholdsvis teorien om sosial kausalitet og teorien om sosial seleksjon (Mossakowski 2014). Opprinnelig var disse to synspunktene eller teoriene konkurrerende forklaringer, men de blir i dag heller ansett som komplementære teorier som sammen kan forklare assosiasionen mellom sosiale forhold og helse (Johnson, Cohen et al. 1999). Empirisk forskning støtter begge teoriene.

Ifølge teorien om sosial kausalitet fører ugunstige sosiale forhold i form av lite sosial støtte, små nettverk, sosial isolasjon eller lav sosioøkonomisk status til forringet mental helse (Mossakowski 2014). Vi kan eksempelvis se for oss at en arbeidsledig alenemor med et lite sosialt nettverk kan føle mye stress i hverdagen, oppleve flere negative livshendelser, ha lav selvfølelse, oppleve lite sosial støtte og ha større sannsynlighet for å utvikle depresjon og selvmordsatferd som et resultat av dette. Den reduserte tilgangen til ressurser slik som kunnskap, penger, emosionell støtte, status og makt, som dårlige sosiale forhold fører til, ansees i følge denne teorien som hovedårsaken til forringet mental helse (Link og Phelan 1995). Teorien om sosial kausalitet er i tråd med forskning som viser at barn som vokser opp i en familie med lav sosioøkonomisk status har økt risiko for blant annet angst, depresion og personlighetsforstyrrelser som 
voksne (McLeod og Shanahan 1996, Johnson, Cohen et al. 1999, Gilman, Kawachi et al. 2002). Likeledes har forskning vist at barn i familier som får hjelp til å komme ut av fattigdom får en reduksjon i andel psykiatriske symptomer (Costello, Compton et al. 2003).

Teorien om sosial seleksjon på den andre siden, fremlegger at psykiske lidelser fører til mindre sosiale nettverk, redusert sosial støtte og forringet sosioøkonomisk status, samt en manglende evne til å forbedre disse dårlige sosiale forholdene (Mossakowski 2014). Denne teorien omtales også som drift-hypotesen for å fremheve forringelsen eller glidningen til et lavere sosialt nivå og mindre sosial støtte. I tråd med denne teorien vil eksempelvis en person med depresion og selvmordsatferd ha støre sannsynlighet for skilsmisse, arbeidsledighet og lite sosial støtte fra familie og venner. Forskning som viser at adferdsforstyrrelser, oppmerksomhetsforstyrrelser og rusmisbruk minker sannsynligheten for fullføring av videregående skole og høyere utdanning støtter teorien om sosial seleksion (Johnson, Cohen et al. 1999, Miech, Caspi et al. 1999, McLeod og Kaiser 2004). Videre har norsk forskning vist at mental uhelse predikerer skilsmisse over en periode på 16 år, og at mennesker med dårlig mental helse dermed selekteres ut av ekteskap (Idstad, Torvik et al. 2015).

\section{Assosiasjonen mellom sosiale forhold og mental helse kan potensielt beskrives som en nedadgående spiral der mental uhelse forringer sosiale forhold, noe som igien bidrar til forverret mental helse.}

Som tidligere nevnt ansees ikke disse to teoriene som konkurrerende forklaringer, men derimot utdypende eller komplementære årsaksforklaringer på relasjonen mellom sosiale forhold og mental helse. Assosiasjonen mellom sosiale forhold og mental helse kan potensielt beskrives som en nedadgående spiral der mental uhelse forringer sosiale forhold, noe som igien bidrar til forverret mental helse. Slik kan sosiale forhold og mental helse vekselvis forringes i en negativ spiral, potensielt med selvmord eller annen selvmordsatferd som utfall. I tillegg har forskning vist at sosial seleksjon og sosial kausalitet har varierende betydning ved ulike psykiske lidelser. Mye kan tyde på at sosial kausalitet spiller en større rolle for utvikling av lidelser som angst og depresion, mens assosiasionen mellom sosiale faktorer og psykiske lidelser henger sterkere sammen med sosial seleksion ved rusmisbruk (Johnson, Cohen et al. 1999). På lik linje kan vi anta at de to ulike prosessene er gieldende for forskjellige former for sosial støtte og sosioøkonomiske faktorer. De store teoriene og årsakssammenhengene kan belyses nærmere giennom å bryte de ned i mindre komponenter og studere spesifikke sammenhenger mellom ulike former for sosiale forhold og forskiellige psykiske lidelser og selvmordsatferd, både ved kvantitativ og kvalitativ forskning.

I tillegg til sosiale forhold vil individuelle egenskaper og atferdsmønstre naturligvis påvirke enkeltmenneskers mentale helse (World Health Organization 2012). Forskning har pekt på en rekke individuelle interne mekanismer relatert til personlighet og genetisk sårbarhet som i stor grad påvirker utviklingen av psykiske lidelser (Sullivan, Neale et al. 2000, Hettema, Neale et al. 2001, Lo, Hinds et al. 2017). I dag vet vi også at individuelle og sosiale faktorer samhandler, og at sosial støtte har en beskyttende effekt giennom en reduksjon i genetisk og miliømessig sårbarhet for psykisk lidelse (Kaufman, Yang et al. 2006). Mental uhelse er dermed resultatet av en svært kompleks og dynamisk interaksion mellom individuelle faktorer og sosiale forhold, og full innsikt i denne smeltedigelen av risiko og resiliens er både vanskelig og på siden av denne artikkelens fokus.

\section{Direkte effekter og buffereffekter}

Sosiale forhold kan påvirke mental helse, slik teorien om sosial kausalitet fremsetter, giennom to ulike prosesser: direkte effekter og buffereffekter (Cohen og Wills 1985). Ifølge hypotesen om direkte effekter har gode sosiale forhold en konstant og overordnet gunstig effekt på mental helse giennom en direkte relasion mellom sosiale forhold og psykisk fungering. Hypotesen om buffereffekter fremlegger derimot at gode sosiale forhold spiller størst rolle i situasioner eller perioder med mer belastende livshendelser ved at de fungerer som en buffer for de negative effektene av disse belastningene. Empiriske studier støtter både hypotesen om direkte effekter (Gjertsen 1998, Burke og Mikkelsen 2007) og hypotesen om buffereffekter (Gerin, Milner et al. 1995, Penninx, VanTilburg et al. 1997, Graham og Barnow 2013).

Sårbare grupper med lav sosial støtte eller sosioøkonomisk status har i følge hypotesen om direkte effekter okt risiko for psykiske lidelser og selvmordsatferd. Tilhørighet og sosial støtte er et sterkt og fundamentalt evolusjonært behov hos mennesker (Baumeister og Leary 1995), og en mangel på dette vil dermed kunne svekke den mentale helsen. Disse direkte effektene av sosiale forhold på mental helse kan blant annet skyldes at dårlige sosiale forhold svekker selvfølelsen og troen på en selv. I tillegg vil andre konsekvenser av dårlige sosiale forhold, slik som et forhøyet stressnivå, en følelse av lite kontroll over eget liv, lav tilgang til ressurser og mange krav både på jobb og hiemmebane, antagelig svekke den mentale så vel som den fysiske helsen (Link og Phelan 1995). Selvrapportering av psykisk stress har vist seg å være redusert blant ungdom som opplever mye støtte fra familie, venner og klassekamerater (Ystgaard 1997). Spesielt var sosial støtte fra familien viktig for den mentale helsen 
til både gutter og jenter. Likeledes har sosial støtte vist seg å redusere forekomsten av selvmordstanker blant norske politibetienter (Burke og Mikkelsen 2007).

I motsetning til hypotesen om direkte effekter fremlegger hypotesen om buffereffekter at gode sosiale forhold først og fremst er avgiørende når man opplever belastende livshendelser eller personlige kriser. Sosial støtte og høy sosioøkonomisk status har dermed en indirekte effekt på psykologisk fungering ved å beskytte mot effekten av negative livshendelser og stress (Cohen og Wills 1985). De negative hendelsene eller belastende situasjonene kan eksempelvis være sykdom, overgrep eller andre traumatiske hendelser slik som voldsepisoder, eller en stressende hverdag med store utfordringer og langvarige problemer. Som et eksempel på buffereffekter viste Ystgaard (1997) at en økning i sosial støtte fra både familie og venner reduserte effekten av negative livshendelser på opplevd psykisk stress.

En mulig forklaring på buffereffekten er at sosial støtte og inkludering kan fremme hensiktsmessige mestringsstrategier og redusere bruken av ugunstige mestringsstrategier. Både problemfokusert mestring, der problemet fjernes eller reduseres, og emosionsfokusert mestring, der det følelsesmessige stresset minimeres, kan forbedres av gode sosiale forhold (Carver og Connor-Smith 2010). For eksempel kan gunstig emosionsfokusert mestring fremmes av emosjonell støtte fra venner og familie, oppmuntring, støttesamtaler og distraksion giennom sosiale aktiviteter. Problemfokusert mestring kan likeledes fremmes av råd eller informasjon fra sosiale nettverk og praktisk hjelp (Dyregrov og Dyregrov 2007). I tillegg kan sosial støtte redusere opplevelsen av hielpeløshet, håpløshet og depresion i en belastende livssituasion (Tezel, Karabulutlu et al. 2011). En ytterligere forklaring på buffereffekten når man opplever negative livshendelser kan være at tilknytning til andre mennesker er en viktig måte å regulere følelser som tristhet, frykt og sorg (Brumariu 2015). Igjen er det viktig å påpeke at indre mekanismer som personlighet og genetisk sårbarhet også har stor påvirkning på mental helse og sammenhengen mellom sosiale forhold og psykisk fungering.

\section{Illustrerende empiriske studier}

En innflytelsesrik storskala registerstudie giennomført i Danmark kan effektivt illustrere teoriene om sosial kausalitet og sosial seleksjon. Qin og medarbeidere (2003) fant at det å være enslig og ha lav utdannelse, inntekt og formue var sterke risikofaktorer for selvmord i den generelle befolkningen sammenlignet med å være gift og ha høy sosioøkonomisk status. I følge teorien om sosial kausalitet kan lav sosial støtte og sosioøkonomisk status lede til nedsatt mental helse og selvmordsatferd. Alternativt kan teorien om sosial seleksjon forklare den forhøyede selvmordsrisikoen ved at dårlig mental helse vil oke sannsynligheten for dårlige sosiale forhold, og på det viset føre til forhøyet selvmordsrisiko.
Antageligvis kan forskningsresultatene best forklares som en nedadgående spiral der sosial kausalitet og sosial seleksion sammen leder til økt selvmordsrisiko, samtidig som en rekke individuelle interne mekanismer naturligvis påvirker utfallet.

Ved Nasjonalt senter for selvmordsforskning og -forebygging (NSSF) i Norge giennomfører vi nå flere registerstudier på innvandreres selvmordsrisiko, og disse studiene kan illustrere hvordan sosiale forhold kan ha en direkte effekt på selvmordsrisiko blant innvandrere. Den innledende studien viste at førstegenerasjons- og andregenerasjonsinnvandrere hadde redusert selvmordsrisiko sammenlignet med etnisk norske, mens norskfødte med én utenlandskfødt forelder og utenlandskfødte med minst én norskfødt forelder hadde økt selvmordsrisiko (Puzo, Mehlum et al. 2017). Videre resultater fra en pågående studie har vist at førstegenerasjonsinnvandrere som lever i hovedstadsområdet Oslo og Akershus har redusert selvmordsrisiko sammenlignet med førstegenerasionsinnvandrere som bor i andre områder av landet. Som vist i Figur 1 står dette i kontrast til etnisk norske som derimot har en okt risiko for selvmord hvis de bor i hovedstadsområdet. En mulig tolkning av disse funnene er at det kan virke beskyttende for førstegenerasjonsinnvandrere å bo i hovedstadsområdet, potensielt fordi dette innebærer større sosial støtte og sosial inkludering fordi dette er det området av landet hvor det bor flest innvandrere (Henriksen, Đstby et al. 2010). Innvandrere i Oslo og

FIGUR 1. Selvmordsrisiko assosiert med bosted blant etnisk norske og førstegenerasjonsinnvandrere. Preliminære resultater av Puzo, Q., Mehlum, L. og Qin, P.

Andre områder Hovedstadsområdet

1,4

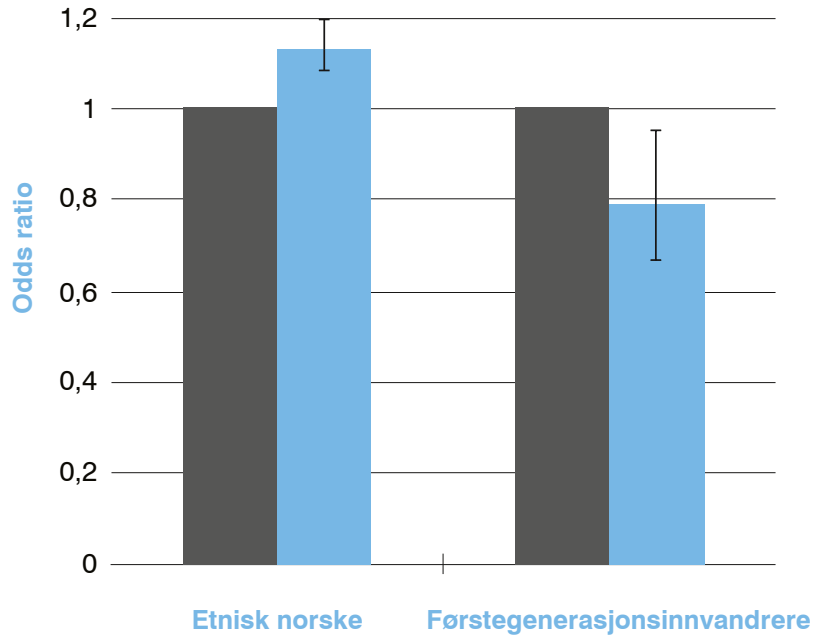


Akershus opplever muligens større sosial inkludering og mindre isolasjon, og har i større grad et nettverk med felles kultur, bakgrunn, tradisjoner og religion. I følge denne mulige forklaringen på forskningsresultatene vil sosial støtte fra andre innvandrere og fra et multikulturelt miliø ha en direkte og konstant effekt på selvmordsrisiko hos førstegenerasionsinnvandrere. Som en ytterligere forklaring kan førstegenerasjonsinnvandrere i hovedstadsområdet skille seg fra førstegenerasjonsinnvandrere i andre deler av landet, noe som kan påvirke selvmordsrisikoen. Innvandrere i Oslo og Akershus kan ha bedre mental helse og sosioøkonomisk status, og innvandrere med muslimsk tro som forbyr selvmord er overrepresentert i hovedstadsområdet (Vrålstad og Wiggen 2016). I tillegg vil selvmordsraten i innvandreres opprinnelige hjemland også påvirke selvmordsraten etter flytting til et nytt land (Ide, Kolves et al. 2012).

Hypotesen om buffereffekter illustreres godt av et annet pågående forskningsprosjekt ved NSSF omhandlende personer som har mistet foreldre ved selvmord, ulykker eller drap. Denne registerstudien har vist at etterlatte har større risiko for selvmord enn personer som ikke har mistet en mor eller far (Burrell, Mehlum et al. 2017a). Som vist i Tabell 1 utgiorde lav sosial støtte, i denne studien uttrykt ved å være enslig

TABELL 1. Selvmordsrisiko assosiert med ulike risikofaktorer blant personer som har mistet foreldre til selvmord, ulykker eller drap. Forkortet og oversatt fra Burrell, Mehlum et al. (2017b).

\begin{tabular}{|c|c|c|}
\hline & Ujustert OR & Justert OR ${ }^{a}$ \\
\hline \multicolumn{3}{|l|}{ Sivilstatus } \\
\hline Gift & 1 (referanse) & 1 (referanse) \\
\hline Aldri gift & $3.63(2.66-4.95)^{\star \star \star}$ & $3.31(2.31-4.74)^{\star * *}$ \\
\hline Separert & $5.81(3.42-9.88)^{\star * *}$ & $3.93(2.20-7.04)^{\star \star *}$ \\
\hline Skilt & $4.05(2.87-5.73)^{\star * *}$ & $2.54(1.66-3.89)^{\star \star *}$ \\
\hline Enke/enkemann & $4.15(1.92-9.00)^{\star \star \star}$ & $3.67(1.60-8.39)^{\star *}$ \\
\hline \multicolumn{3}{|l|}{ Endringer i sivilstatus } \\
\hline Ingen endring & 1 (referanse) & 1 (referanse) \\
\hline Én endring & $0.94(0.69-1.28)$ & $1.17(0.76-1.82)$ \\
\hline To eller flere endringer & $1.85(1.36-2.50)^{\star \star *}$ & $1.77(1.10-2.84)^{*}$ \\
\hline \multicolumn{3}{|l|}{ Endringer i bosted } \\
\hline Ingen endring & 1 (referanse) & 1 (referanse) \\
\hline Én endring & $1.43(1.06-1.92)^{*}$ & $1.28(0.94-1.73)$ \\
\hline To eller flere endringer & $1.87(1.41-2.49)^{\star \star *}$ & $1.56(1.16-2.10)^{\star \star}$ \\
\hline \multicolumn{3}{|l|}{ Inntekt } \\
\hline$>400001$ NOK & 1 (referanse) & 1 (referanse) \\
\hline $300001-400000$ NOK & $1.25(0.81-1.92)$ & $1.04(0.67-1.61)$ \\
\hline 200 001-300 000 NOK & $1.98(1.35-2.92)^{\star \star *}$ & $1.45(0.97-2.16)$ \\
\hline 100 001-200 000 NOK & $4.50(3.09-6.57)^{\star * *}$ & $2.97(1.99-4.41)^{\star \star *}$ \\
\hline$<100000$ NOK & $4.36(2.80-6.79)^{\star \star \star}$ & $2.93(1.85-4.63)^{\star \star *}$ \\
\hline \multicolumn{3}{|l|}{ Utdanning } \\
\hline Нøу & 1 (referanse) & 1 (referanse) \\
\hline Medium & $1.47(1.08-1.99)^{*}$ & $1.36(0.99-1.88)$ \\
\hline Lav & $2.20(1.61-3.01)^{\star \star \star}$ & $1.60(1.15-2.23)^{\star \star}$ \\
\hline \multicolumn{3}{|l|}{ Etnisitet } \\
\hline Etnisk norsk & 1 (referanse) & 1 (referanse) \\
\hline Innvandringsbakgrunn & $1.55(1.06-2.26)^{*}$ & $1.51(1.02-2.25)^{*}$ \\
\hline
\end{tabular}

Risiko oppgis i odds ratio med $95 \%$ konfidensintervall i parentes.

a Selvmordsrisiko justert for alle variablene i studien. * $p<.05,{ }^{* *} p<.01,{ }^{* * *} p<.001$ signifikansnivå. 
eller ha byttet partner eller bosted mer enn to ganger, den største risikofaktoren for selvmord blant dem som hadde mistet en eller to foreldre til slike ytre dødsårsaker (Burrell, Mehlum et al. 2017b). Å oppleve sosial støtte er dermed en beskyttende faktor for etterlatte, til og med flere tiår etter tapet, i forhold til ikke å ha slik sosial støtte. Videre er lav sosioøkonomisk status også en risikofaktor for selvmord blant denne gruppen (Burrell, Mehlum et al. 2017b) (Tabell 1). Det er antagelig flere mulige årsaker til sammenhengen mellom dårlige sosiale forhold og selvmordsrisiko etter tap av foreldre, blant annet at sosial støtte og høy sosioøkonomisk status fungerer som en buffer ved å beskytte mot effekten av tap av foreldre på selvmordsrisiko. Disse funnene fra storskala registerstudier som viser at gode sosiale forhold fungerer som viktige ressurser for etterlatte på tvers av alder og kjønn, samsvarer godt med norsk kvalitativ forskning på samme problemstillinger (Dyregrov og Dyregrov 2007). Dessverre er tap av nær familie eller nære venner en spesielt problematisk livshendelse for individer med lite sosial støtte, fordi tapet i seg selv innebærer en kraftig svekkelse i tilgiengelig sosial støtte.

Det er viktig å merke seg at både direkte effekter og buffereffekter av sosiale forhold naturligvis vil være gieldende for de to populasionene presentert her, henholdsvis innvandrere og etterlatte, på forskjellige tidspunkter og i forskjellige situasioner giennom livet.

\section{Implikasjoner}

Kunnskapen som fremlegges giennom de ulike teoriene om sosiale forhold er viktig, både på et personlig mellommenneskelig nivå og på et høyere strukturelt samfunnsnivå, og sammen med de empiriske studiene nevnt over peker de mot en del praktiske implikasjoner av den genererte kunnskapen. På bakgrunn av de nye funnene om selvmordsrisiko blant innvandrere i Norge vil integrering av innvandrere potensielt bedre deres sosiale forhold og redusere psykiske lidelser og selvmord. For etterlatte etter selvmord er det viktig at opplysningsarbeid og annet forebyggende arbeid fokuserer på å mobilisere nettverk og støtte. Arbeidet til LEVE (Landsforeningen for etterlatte ved selvmord) og Unge LEVE er viktig, og likepersonsarbeid og sorggrupper kan fremme sosial støtte og redusere følelsen av isolasion, stigmatisering og ensomhet. Intervensionsprogrammer for etterlatte som fokuserer på økt sosial støtte i form av bedre familieforhold har på lik linje vist seg å føre til bedret mental helse (Tein, Sandler et al. 2006). Også i behandlingstiltak for personer som har kompliserte former for sorg er det viktig å integrere sosiale støttetiltak (Shear 2015).

I tillegg til populasjonene som er undersøkt i de empiriske studiene presentert over, gir de ulike teoriene om sammenhengen mellom sosiale forhold og forekomst av selvmord grunn til å anta at det også for andre sårbare grupper og individer utsatt for negative livshendelser, vil være viktig å fokusere på økt sosial

\section{Primærhelsetjenesten og flere andre kommunale tienester har sannsynlig- vis fortsatt mer å hente ved å styrke pasienters evne til å være aktive på sosiale arenaer og vedlikeholde sine sosiale nettverk.}

støtte som en del av forebygging så vel som behandling. Naturligvis trengs inngående studier med forståelsesrammer fra nærliggende fagfelt for å fastslå de ulike forebyggende og behandlende tiltakene, så vel som de bakenforliggende prosessene som driver en eventuell endring. Arbeidet til en rekke brukerorganisasjoner er fordelaktig ved å gi personer i krise eller særlig belastende livssituasioner sosial støtte utover det som øvrig sosialt nettverk kan gi (Dyregrov og Dyregrov 2007). Krisetelefoner, chattetienester, eller internettfora, slik som Røde Kors sin tjeneste «Kors på halsen», kan gi samme støtte i en belastende situasjon. I lys av sammenhengen mellom lav sosioøkonomisk status og redusert mental helse hos både voksne og barn (Costello, Compton et al. 2003, Qin, Agerbo et al. 2003) vil økonomiske så vel som sosiale tiltak rettet mot vanskeligstilte kunne bedre deres psykiske fungering. Et annet eksempel på bedring av sosiale forhold for sårbare grupper er bedring av soningsforhold for fanger, blant annet giennom soning i lavsikkerhetsfengsel eller overgangsbolig, straffegiennomføring med elektronisk kontroll (fotlenke), samt oppfølging etter løslatelse. Primærhelsetjenesten og flere andre kommunale tienester har sannsynligvis fortsatt mer å hente ved å styrke pasienters evne til å være aktive på sosiale arenaer og vedlikeholde sine sosiale nettverk.

I tråd med teoriene om sosial støtte har involvering av pårørende i behandling og utvikling av tienestetilbud i psykisk helsevern vist seg å øke pasienters psykiske helse (Helsedirektoratet 2014). Som vist i en tidligere undersøkelse i Norge opplever mange at betydningen av sosialt nettverk kan bli oversett av behandlere (Granerud 2004). Særlig i psykisk helsevern er det viktig med et økt fokus på involvering av familie og økning i sosial støtte. Tiltak rettet mot å bedre pasientens sosiale ferdigheter har vist seg å kunne redusere psykiske symptomer (Dilk og Bond 1996, Kopelowicz, Liberman et al. 2006). Dagens økte fokus på tilrettelagt arbeid og utdanning (Helsedirektoratet 2014) kan forhåpentligvis på lik linje gi pasienter i psykisk helsevern bedre mental helse giennom økt sosial tilhørighet og sosioøkonomisk status. I tillegg til et fokus på pasienten, vil støtte og hjelp til pårørende kunne være med å bedre pasienters mentale helse giennom å giøre nettverket rundt pasienten bedre rustet til å gi sosial støtte. Eksempelvis har psykoedukasjon av pårørende vist seg å bedre pasienters psykiske helse (Center for Mental Health 
Services 2009). Familie- eller parterapi kan også være gunstig for å øke tilhørighet og sosial støtte for både pasient og pårørende, samt støtte familier i konflikt (Helsedirektoratet 2014). Ulike pårørendeorganisasjoner vil likeledes være gunstige for å gi støtte til det sosiale nettverket til pasienter i psykisk helsevern. Pasienter innen somatisk helsevern vil også kunne ha positiv effekt av et fokus på sosial støtte, involvering av familie i tienestetilbudet og tilrettelagt arbeid og utdanning.

De overordnede teoriene om sammenhengen mellom sosiale forhold og mental helse fremlegger dermed at dårlige sosiale forhold forårsaker dårlig helse eller at psykiske lidelser forringer individers sosiale forhold. Negative eller ugunstige sosiale forhold kan på sin side forårsake psykisk uhelse giennom direkte effekter eller giennom indirekte buffereffekter, der gunstige sosiale forhold reduserer påvirkningen av negative livshendelser eller belastende situasioner. I virkeligheten er det ofte vanskelig å skjelne hvorvidt assosiasjonen mellom sosiale forhold og mental helse er kausal eller selektiv, eller hvorvidt sammenhengen skyldes en direkte- eller buffereffekt. Med påvirkningen fra genetiske og miliømessige faktorer så vel som deres interaksion er forholdet mellom sosiale forhold og psykisk lidelse mer komplisert enn de presenterte teoriene viser. Likevel er det viktig lærdom å ta med seg fra de ulike teoriene om sosiale forhold presentert over: Gode sosiale forhold med mye sosial støtte er bra for den mentale helsen.

Levert: 19.09.17 - Revidert: 11.11.17 - Godkjent: 13.11.17

\section{REFERANSELISTE}

Baumeister, R. F. og M. R. Leary (1995). The need to belong - Desire for interpersonal attachment as a fundamental human motivation. Psychological Bulletin 117(3): 497-529.

Brumariu, L. E. (2015). Parent-Child Attachment and Emotion Regulation. Attachment in Middle Childhood: Theoretical Advances and New Directions in an Emerging Field. G. Bosmans and K. A. Kerns. San Francisco, Wiley Periodicals. 148: 31-45

Burke, R. I. og Mikkelsen, A. (2007). Suicidal ideation among police officers in Norway. Policing-an International Journal of Police Strategies \& Manage ment 30(2): 228-236.

Burrell, L. V., Mehlum, L. og Qin, P. (2017a). Sudden Parental Death from External Causes and Risk of Suicide in the Bereaved Offspring: A National Study. Journal of Psychiatric Research 96: 49-56.

Burrell, L. V., Mehlum, L. og Qin, P. (2017b). Risk factors for suicide in offspring bereaved by sudden parental death from external causes. Journal of Affective Disorders 222: 71-78.

Carver, C. S. og Connor-Smith, I. (2010). Personality and Coping. Annual Review of Psychology 61: 679-704.

Center for Mental Health Services (2009). The Evidence: Family Psychoeducation. E.-b. p. K. I. Transformation. Rockville, MD. SMA-og-4422

Cohen, S. og Wills, T. A. (1985). Stress, social support, and the buffering hypothesis. Psychological Bulletin 98(2): 310-357.
Costello, E. I., Compton, S. N., Keeler, G. og Angold, A. (2003). Relationships between poverty and psychopathology - A natural experiment. IamaJournal of the American Medical Association 290(15): 2023-2029.

Dilk, M. N. og Bond, G. R. (1996). Meta-analytic evaluation of skills training research for individuals with severe mental illness. Journal of Consulting and Clinical Psychology 64(6): 1337-1346.

Durkheim, E. (1897/1966). Suicide (oversatt av T.A. Spaulding \& G. Simpson). New York (utkom forste gang i 1897), The Free Press.

Dyregrov, K. og Dyregrov, A. (2007). Sosial nettverksstøtte ved brå død. Bergen, Norge, Fagbokforlaget.

Gerin, W., Milner, D., Chawla, S. og Pickering, T. G. (1995). Social suppoert as a moderator of cardiovascular reactivity in women - A test of the direct effects and buffering hypotheses. Psychosomatic Medicine 57(1): 16-22.

Gilman, S. E., Kawachi, I., Fitzmaurice, G. M. og Buka, S. L. (2002). Socioeconomic status in childhood and the lifetime risk of major depression. International Journal of Epidemiology 31(2): 359-367.

Gjertsen, H. (1998). Selvmord blant eldre menn - i et virksomhetsteoretisk perspektiv. Suicidologi 3: 16-17.

Graham, I. M. og Barnow, Z. B. (2013). Stress and Social Support in Gay, Lesbian, and Heterosexual Couples: Direct Effects and Buffering Models. Journal of Family Psychology 27(4): 569-578.

Granerud, A. (2004). Sosial integrering for mennesker med psykiske problemer - erfaringer, utfordringer og ønsket støtte. Elverum, Høgskolen i Hedmark.

Helsedirektoratet (2014). Sammen om mestring: Veileder i lokalt psykisk helsearbeid og rusarbeid for voksne. Et verktoy for kommuner og spesialisthelsetienesten. Helsedirektoratet.

Henriksen, K., L. Đstby og D. Ellingsen (2010). Immigration and immigrants, Oslo/Kongsvinger, Norway, Statistics Norway.

Hettema, I. M., Neale, M. C. og Kendler, K. S. (2001). A review and metaanalysis of the genetic epidemiology of anxiety disorders. American Journal of Psychiatry 158(10): 1568-1578.

Ide, N., Kolves, K., Cassaniti, M. og De Leo, D. (2012). Suicide of first-generation immigrants in Australia, 1974-2006. Social Psychiatry and Psychiatric Epidemiology 47(12): 1917-1927.

Idstad, M., Torvik, F. A., Borren, I., Rognmo, K., Roysamb, E. og Tambs, K. (2015). Mental distress predicts divorce over 16 years: the HUNT study. Bmc Public Health 15: 10.

Johnson, J. G., Cohen, P., Dohrenwend, B. P., Link, B. G. og Brook, I. S. (1999). A longitudinal investigation of social causation and social selection processes involved in the association between socioeconomic status and psychiatric disorders. Journal of Abnormal Psychology 108(3): 490-499.

Kaufman, I., Yang, B. Z., Douglas-Palumberi, H., Grasso, D., Lipschitz, D., Houshyar, S., Krystal, I. H. og Gelernter, I. (2006). Brain-derived neurotrophic factor-5-HTTLPR gene interactions and environmental modifiers of depression in children. Biological Psychiatry 59(8): 673-680.

Kleiman, E. M. og Liu, R. T. (2013). Social support as a protective factor in suicide: Findings from two nationally representative samples. Journal of Affective Disorders 150(2): 540-545.

Kopelowicz, A., Liberman, R. P. og Zarate, R. (2006). Recent advances in social skills training for schizophrenia. Schizophrenia Bulletin 32: S12-S23.

Link, B. G. og Phelan, I. (1995). Social conditions as fundamental causes of disease. Journal of Health and Social Behavior 35: 80-94.

Lo, M. T., Hinds, D. A., Tung, I. Y., Franz, C., Fan, C. C., Wang, Y. P., Smeland, O. B., Schork, A., Holland, D., Kauppi, K., Sanyal, N., Escott-Price, V., Smith, D. I., O'Donovan, M., Stefansson, H., Biornsdottir, G., Thorgeirsson, T. E., Stefansson, K., McEvoy, L. K., Dale, A. M., Andreassen, O. A. og Chen, C. H. (2017). Genome-wide analyses for personality traits identify six genomic loci and show correlations with psychiatric disorders. Nature Genetics 49(1): $152-156$. 
McLeod, I. D. og Kaiser, K. (2004). Childhood emotional and behavioral problems and educational attainment. American Sociological Review 69(5): 636-658.

McLeod, I. D. og Shanahan, M. I. (1996). Trajectories of poverty and children's mental health. Journal of Health and Social Behavior 37(3): 207-220.

Miech, R. A., Caspi, A., Moffitt, T. E., Wright, B. R. E. og Silva, P. A. (1999). Low socioeconomic status and mental disorders: A longitudinal study of selection and causation during young adulthood. American Journal of Sociology 104(4): 1096-1131.

Mossakowski, K. N. (2014). Social Causation and Social Selection. The Wiley Blackwell Encyclopedia of Health, Illness, Behavior, and Society. W. C. Cockerham, R. Dingwall and S. R. Quah, John Wiley \& Sons, Ltd.

Penninx, B., VanTilburg, T., Deeg, D. I. H., Kriegsman, D. M. W., Boeke, A. I. P. og VanEijk, I. T. M. (1997). Direct and buffer effects of social support and personal coping resources in individuals with arthritis. Social Science \& Medicine 44(3): 393-402.

Puzo, Q., Mehlum, L. og Qin, P. (2017). Suicide among immigrant population in Norway: a national register-based study. Acta Psychiatrica Scandinavica 135(6): 584-592.

Qin, P., Agerbo, E. og Mortensen, P. B. (2003). Suicide risk in relation to socioeconomic, demographic, psychiatric, and familial factors: A national register-based study of all suicides in Denmark, 1981-1997. American Tournal of Psychiatry 160(4): 765-772.

Shear, M. K. (2015). Complicated Grief Treatment - Instruction manual used in NIMH grants Columbia Center for Complicated Grief.

Sullivan, P. F., Neale, M. C. og Kendler, K. S. (2000). Genetic epidemiology of major depression: Review and meta-analysis. American Journal of Psychiatry 157(10): 1552-1562.

Tein, I. Y., Sandler, I. N., Ayers, T. S. og Wolchik, S. A. (2006). Mediation of the effects of the family bereavement program on mental health problems of bereaved children and adolescents. Prevention Science 7(2): 179-195.

Tezel, A., Karabulutlu, E. og Sahin, O. (2011). Depression and perceived social support from family in Turkish patients with chronic renal failure treated by hemodialysis. Journal of Research in Medical Sciences 16(5): 666-673.

Thorsen, K. og Clausen, S. E. (2009). Hvem er de ensomme? Lest 11.07.2017. from https://www.ssb.no/sosiale-forhold-og-kriminalitet/artikler-ogpublikasjoner/hvem-er-de-ensomme.

Vrålstad, S. (2017). Sosiale relasioner. Lest 11.07.2017, from https://www. ssb.no/sosiale-forhold-og-kriminalitet/artikler-og-publikasjoner/sosialerelasioner.

Vrålstad, S. og Wiggen, K. S. (2016). Levekår blant innvandrere i Norge. Oslo/Kongsvinger, Norge, Statistisk sentralbyrå.

World Health Organization (2012). Risks to mental health: An overview of vulnerabilities and risk factors. W. H. Organization, World Health Organization: 1-14

Ystgaard, M. (1997). Life stress, social support and psychological distress in late adolescence. Social Psychiatry and Psychiatric Epidemiology 32(5): $277-283$.

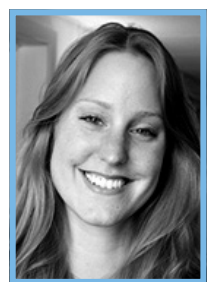

LISA VICTORIA BURRELL er doktorgradsstipendiat i gruppen for registerforskning på selvmord og villet egenskade ved NSSF, Institutt for klinisk medisin, Universitetet i Oslo. Hun har en mastergrad $\mathrm{i}$ kognitiv nevropsykologi fra Psykologisk institutt ved Universitetet i Oslo.

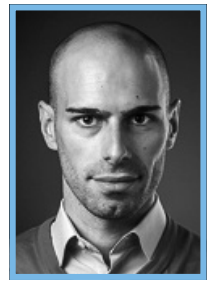

QUIRINO PUZO er doktorgradsstipendiat ved NSSF, Institutt for klinisk medisin, Universitet i Oslo. Han forsker på selvmord blant innvandrere i Norge og har mastergrad i statistikk fra Universitetet i Sannio, Benevento i Italia.

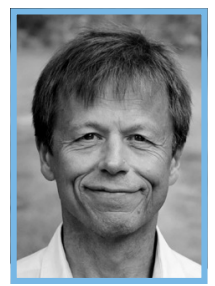

LARS MEHLUM er professor dr. med. og leder av NSSF, Institutt for klinisk medisin, Universitetet i Oslo.

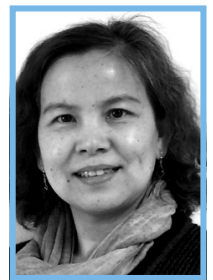

PING QIN er professor, dr.med., spesialist i psykiatrisk epidemiologi ved NSSF, Institutt for klinisk medisin, Universitetet i Oslo. Hun er gruppeleder av registerforskning på selvmord og villet egenskading. 